\title{
An Ethnographic Approach to School Convivencia
}

\author{
Cristina Perales Franco' \\ 'University College London (UCL), London - United Kingdom
}

\begin{abstract}
An Ethnographic Approach to School Convivencia. Convivencia is a Spanish concept that addresses the ways of living together, living with others. School convivencia in particular is formed by the tapestry of social relations that construct the everyday life in schools, and it provides the relational elements and boundaries where the school experience is constructed. This article derives from an investigation of the relationships between two Mexican primary schools and their local communities and their implications for school convivencia. It presents two challenges of analysing school convivencia from an ethnographic perspective: the struggle between restrictive and comprehensive approaches and the tension between the specific and the complex in understanding convivencia.
\end{abstract}

Keywords: School Convivencia. Ethnography. Community-School Relationships. School Violence. School Coexistence.

RESUMO - Abordagem Etnográfica à Convivência na Escola. Convivência é um conceito que se refere a maneiras de conviver, de viver com os outros. A convivência na escola, em especial, é formada pela trama de relações sociais que constroem a vida cotidiana nas escolas, fornecendo os elementos e os limites relacionais sobre os quais a experiência da escola é construída. Este artigo resulta de uma investigação sobre as relações entre duas escolas de ensino fundamental mexicanas e suas comunidades locais e suas implicações para a convivência na escola. Apresenta dois desafios ao analisar a convivência na escola a partir de uma perspectiva etnográfica: um conflito entre abordagens restritivas e abrangentes e a tensão entre o específico e o complexo ao compreender a convivência.

Palavras-chave: Convivência na Escola. Etnografia. Relações Comunidade-Escola. Violência na Escola. Coexistência na Escola.

Educação \& Realidade, Porto Alegre, v. 43, n. 3, p. 887-907, July/Sept. 2018. 887 http://dx.doi.org/10.1590/2175-623674800 
An Ethnographic Approach to School Convivencia

\section{Introduction}

School convivencia addresses ways of living together and living with others that happens in school, focussing on the quality of interpersonal relationships among the school actors. In different Latin American countries, such as Chile (Chile, 2002), Peru (Peru, 2015), Argentina (Argentina, 2010) and Mexico (Mexico, 2014) the work on school convivencia has become an explicit part of their educational policies, emphasizing the need in these countries of a safe and positive convivencia to counteract school violence and provide an appropriate context for the development of learning processes. Convivencia as an academic and practice field is still emergent, and the concept is present in different studies and programmes in the areas of Peace, Human Rights, Citizenship, Inclusive, Intercultural and Moral Education, among others. These works have helped to shape particular claims regarding the appropriate traits that ought to characterise school convivencia. The three main claims are that convivencia should be democratic, inclusive and should promote a peace culture. Aspects that are considered crucial to the fulfilment of the right to education (Evans, 2013; UNESCO, 2009).

The multiplicity of social relations that constitute the everyday life in educational institutions shape school convivencia, and therefore it is produced and reproduced by the quotidian shared experiences among students, teachers, parents, administrative staff and other members of the community. To study school convivencia is to analyse the characteristics and implications of such relationships and how they construct a way of living together. The research in this field has been undertaken for different purposes, such as to analyse educational policy (Rivera, 2012), to develop instruments to assess the convivencia in particular schools, cities or states (Caso-López et al., 2015; Evans et al., 2013a), to look at the relationship between some forms of school convivencia and bullying practices (Ortega-Ruiz; Del Rey; Casas, 2013) , to reflect on best practices of convivencia (Caballero Grande, 2010; Evans; Ollivier, 2012), etc. Each of these areas of research addresses specific elements of the concept of convivencia and the way it is experienced in school. In this text I refer to the analysis of school convivencia from an ethnographic perspective, which aims to address the elements of the concept by situating them in concrete, multi-layered and historically and culturally situated contexts.

The aim here is therefore to explore the use of ethnography as a relevant approach to researching school convivencia, and to point out the contributions that an in-depth understanding of local cultures and practices can have to the development of our understanding of the processes of convivencia. The article highlights the necessity of recognizing and dealing with the links between theoretical and methodological components of research and their role in shaping the data collection process. This argument is exemplified by exploring two tensions that were experienced while undertaking fieldwork for a particular research project. The first is the tension between the actors and the researcher's

888 Educação \& Realidade, Porto Alegre, v. 43, n. 3, p. 887-907, July/Sept. 2018. 
different views on what convivencia entailed and the repercussion of such understandings when constructing data. The second tension describes the challenges in setting boundaries on a complex and interrelated concept such as convivencia and dealing with the fragmentation risk, in order to analyse everyday action without separating them from their context. I argue that these are challenges to resolve by any researcher of the study of convivencia in the everyday life of schools. I will start by analysing further the concept of convivencia, and then move to look at how the concept has been used in different research and intervention processes. I will then introduce ethnography as a method of research, pointing out its relevance for the study of convivencia. Finally I will explore the two tensions that emerged during the fieldwork undertaken during my $\mathrm{PhD}$ research. In the next section I will address more fully the notion of convivencia and start to delineate why the elements of an ethnographic approach present opportunities for the study of this phenomenon.

\section{Notion of School Convivencia}

Convivencia can be understood as the engaged and meaningful coexistence relationships between humans. It emerges from the "[...] continuous use and practice of the cultural resources that are available to people in a concrete society through their different membership groups" (Franco; Parada; Castañeda, 2013, p. 150, translated from Spanish). People have resources that they take from their family, school, work environment, neighbourhood, city, and so on, and these resources come into play to shape the type of relationships they engage in. Such relationships are organized by certain common value codes in established social and cultural contexts (Jares, 2006). Convivencia does not necessarily imply that everybody has the same values, or that the relationship between the people in a concrete setting must be harmonious in order to live together: rather, it means that people adopt certain patterns that allow and shape the living together in specific communities. Convivir relates to the way each of us are in relation to others.

The shaping of convivencia is a continuous constructive process that is based on transactions, negotiations of actions and meanings, and patterns of organization. Through living together people construct common meanings that provide a natural way of doing things that moulds the identities of different groups. In this way, the models of convivencia are historically and culturally constructed: to live together means to interact in the framework of groups' identities, expressed through particular relationships, logics of action and installed in meanings, values and beliefs (Hirmas; Eroles, 2008).

Convivencia in schools is a particular type of convivencia that is formed by the tapestry of social relations that construct everyday life in these educational institutions (Parada, 2009). The type of convivencia that a school has shapes the schooling experience of the students, but also the experiences of the teachers, the parents and other actors 
involved. It provides the relational elements and boundaries through which the school experience is constructed. To consider convivencia in schools is to focus on the quality - in the sense of both characteristics and attributed values - of the interpersonal relationships that are constructed in the institution (Ararteko, 2006, p. 39) and the implications of such quality in other aspects like learning, moral development, conflict management and possibilities of participation.

Convivencia is learned and taught through the school experience (Ianni, 2003). On the one hand, there are specific curricular strategies that deal with the accepted ways of relating to each other in school, for example the school's rules of behaviour, peace and conflict management programmes or citizenship courses. Such strategies could be understood as school's explicit processes of convivencia. On the other hand, convivencia is constantly being shaped in the day to day practices of interacting and interrelating among all school actors, in what could be called the school's tacit processes of convivencia; these may include actions such as dialoguing, participating, compromising, obeying, arguing, dissenting, fighting, agreeing, reflecting, etc. Explicit and tacit processes combine and are put into action in the everyday life of the school through activities, projects and in the common and multiple interactions that lead to accepted, naturalized, ways of living together. The particular type of convivencia that is developed in school shapes, and is shaped by, the roles and manners of engagement of the school's actors; it is learned by the act of actually engaging in the process of living together. All educational processes, therefore, involve learning specific types of convivencia (Jares, 2006, p. 11), which present for the school's actors the contextually permissible and normative ways of interacting, participating and relating to each other.

Although certain types of convivencia are promoted by the school and the educational system in general, one must not forget that convivencia is shaped by the continuous social relations that take place in schools, and therefore the particular ways in which it is manifested vary depending on the actors, their practices, and on the spaces that they occupy. UNESCO's matrix for democratic convivencia and peace culture (Hirmas; Carranza, 2009) separates the practices of the classroom, the school as an institution, and the school in relation to the community. In these three areas or dimensions, the actors play various roles in shaping convivencia, and, as such the processes are of a very different character and have diverse implications for the schooling experience.

One must also consider that school is not the only social institution where convivencia is shaped; it also arises from other social areas like family, peer groups, the whole educational system, religious institutions, mass communication media, as well as political and economic contexts (Jares, 2006; Onetto, 2004). The different models of convivencia that emerge from these different institutions and spheres interact and have an impact on the school's relationships. For this reason it is necessary to locate the school convivencia inside wider historical, social and cultural processes, and to consider the broader context of the institu- 
tion and the way that processes and resources are put into practice in the particular setting (Evans et al., 2013a).

There seems to be an under-theorization in the academic literature of, firstly, the role of the actors and their relationships in shaping convivencia, since more attention has been given to the description and analysis of the traits of convivencia in a setting based on an ideal of how convivencia should be, what has been called by Evans et al. (2013b) a normative-prescriptive approach. Secondly, previous studies in this area have focused particularly on the classroom and school levels of convivencia, and although the literature on this topic points out the importance of the community level (e.g. Evans, 2013; Vázquez, 2009; Hirmas; Eroles, 2008; Onetto, 2004; UNESCO, 2009), there are very few studies that empirically explore the relationships with this focus. One of the central arguments of this paper is that in order to understand the type of convivencia that is practiced in each school and how such convivencia is shaped by the social actions, one needs to consider the different practices, as well as their layers and patterns, and therefore one should study convivencia through a method that will allow one to explore such complexity. Ethnography is particularly well-suited for the task, since ethnographic accounts provide rich empirical data that could allow to theorise on the ways actors engage in convivencia in multi-levelled relationships.

The concept of convivencia is deemed particularly important in formal educational processes for three key reasons. Firstly, schools have been socially positioned as the main institutions responsible for shaping citizens and therefore, for the education of students in the norms of appropriate social behaviour. Since such learning happens mainly through social interactions, the type of convivencia the school has can reinforce or hinder the citizen education processes. Secondly, as various studies have illustrated (Casassus, 2005; OECD, 2013; UNESCO, 2008) the characteristics of the social interactions that happen in schools have repercussion for the quality of the learning process and results. For example, the Second Regional Comparative and Exploratory Study undertaken by UNESCO and LLECE in Latin-America and the Caribbean, postulates the importance of harmonious and positive human relationships inside the school: they found that positive school climate, measured in terms of quality of interactions, is the most important variable to explain students' performance in maths, reading, and sciences (UNESCO, 2008, p. 157).

Thirdly, the focus on convivencia in schools is important because schools can actually intentionally promote or transform a determinate model of convivencia. In this line Jares (2006, p. 12) establishes that:

Even if it is true that learning to convivir has a great deal of unintentional social osmosis, and therefore, hardly predictable borders, it is not less true that social circumstances planned in a set way - e.g. by promoting respectful, plural and democratic relationships - can facilitate,

Educação \& Realidade, Porto Alegre, v. 43, n. 3, p. 887-907, July/Sept. 2018. 
and in fact do, processes and social relations in the mentioned direction ${ }^{1}$.

This possibility of shaping the model of convivencia into what is considered a better one is a constant trait of the literature of this field, especially when in many cases it is not until convivencia is perceived as problematic that the social relationships among the school actors are reflected on, analysed and/or intervened in. In the following section I will present some of the approaches used to address school convivencia and its implications.

\section{Understanding and Intervening in School Convivencia}

As Ianni (2003) clearly points out, convivencia in schools is not a new phenomenon or concept, as social interactions that shape ways of living together have always been part of educational processes. What has changed is the understanding of the relationship between the educational actors; because adults and children are now considered to be subjects of rights and responsibilities, school convivencia must respect and promote such conventions, and relational practices should be analysed, understood and transformed so that they ensure the fulfilment of human rights, especially the right to education of the students and their right to a life free of violence (Donoso, 2012). It is in this conception of convivencia that elements like inclusion, democracy, peace, exclusion, violence, participation, etc. become intertwined with the visibility of the type of convivencia in schools.

There are broadly two reasons why an appropriate convivencia relates to the human rights perspective. On the one hand, convivencia is important because of its impact on the schools' expected outcomes: an appropriate convivencia is required for the development of the learning process. This becomes particularly evident through the studies of school violence which show the implications of how such phenomena hinder the possibility of the students to learn. On the other hand, it is significant because the learning of certain types of convivencia is in itself a desirable outcome of the learning process, as the influential Delors report for UNESCO in 1996 establishes:

'Learning to live together, learning to live with others' constitute an important educational challenge. It assumes to fulfil a double mission: to teach the diversity of the human species and contribute, at the same time, to an acknowledgement of the similarities, differences and interdependence of all the human beings (Delors, 1997, p. 104 apud Vázquez, 2009, p. 125).

In this sense, to learn to convivir becomes a basic goal of education (Vázquez, 2009, p. 126) ${ }^{2}$.

The orientations these two reasons provide shape different approaches on how to understand, manage and improve school convivencia, which in turn are reflected in the academic literature ${ }^{3}$, in school 
policy and in the everyday practices in the schools. Padilla (2013) who looks at convivencia through the notion of democratic participation in schools, establishes that there are two main approaches to convivencia, which she labels as restricted and comprehensive. The first one is focused on the need to decrease the level of school violence, "[...] emphasising the control of the aggressive behaviour of the students" (Padilla, 2013, p. 15). This approach is usually associated with the development of individual emotional changes in pupils and/or in the creation of regulations to deal with violence. For Padilla this approach is related to the idea of negative peace and peace keeping that Galtung (1969; 1976; 1996) proposes.

Different people studying school convivencia stress that this approach is problematic since it reinforces the idea that students, as individuals, are responsible for school violence (Gladden, 2002; Harris, 2004; Vaandering, 2010 apud Padilla, 2013, p. 16), without taking into account how the schools' relations and structures reproduce or increase it. Evans et al. (2013) maintain that approaches of this type are ineffective because they "[...] tend to condone or promote the human rights violation in the name of a certain 'order' unilaterally established by those who are the authority, leaving intact, at the same time, the profound causes that originate such phenomena" (Akiba et al., 2002 et al. apud Evans, 2013, p. 104). This restrictive approach reduces the role of convivencia to a technical element related to a type of learning that is focused on individual academic achievements, undermining the meaningful social learnings that emerge from the everyday convivencia.

The second approach, referred to by Padilla (2013) as a comprehensive approach, "[...] integrates the democratic relationships (institutional, cultural and personal) as well as the participation structures as essential elements for peace construction and consolidation" (Padilla, 2013, p. 15). Her notion of democracy takes account of power distribution and processes of conflict resolution, and in that sense democracy is understood as "[...] a way of solving the conflicts and of fair convivencia that must be practiced in any place where social exchange takes place" (Maggi, 2007, p. 9 apud Padilla, 2013, p. 15). This wider way of understanding convivencia is related to a positive notion of peace and to the processes of peace making and peace building that Galtung (1969; 1976; 1996) proposes. It is understood as democratic convivencia because it assumes the "[...] construction of just and long-lasting interpersonal, institutional and cultural relationships that offer all students an equal access to an education with quality" (Padilla, 2013, p. 17). As we can see, this perspective takes into consideration that social relationships are part of the school experience and are intrinsically related to the quality of education. Padilla (2013) places a specific type of convivencia as a way of constructing and exercising peace, inclusion, citizenship and democracy. In this comprehensive view, convivencia is not just a variable to be transformed to reduce violence and in turn improve learning outcomes, but as a way of educating and a goal of education in itself. 
The comprehensive approach links together powerful notions of participation, equality, inclusion and quality in education, situating the notion of school convivencia outside of a mere instrumental function of managing students' behaviour. Certain types of convivencia become educational processes aimed to construct a better society. When analysing convivencia this view is not without challenges, since the complexity it presents makes it hard to locate the boundaries for data collection and analysis, as I will describe through the two tensions presented in the third part of this article.

So far, this paper has presented the notion of school convivencia, describing it as emerging from the continuous engaged relationship among school actors that shape everyday life in educational institutions. It has also presented two approaches to understanding and intervening in school convivencia (Padilla, 2013): a restrictive approach based in managing the behaviour of the students and a comprehensive approach, that integrates a complex view of the concept, linking it to democratic and participation perspectives as a goal and orientation of the process of living together and learning to live together in schools. In the following section I will describe what ethnography as a method for qualitative analysis is, arguing that the openness in the research design, the multiplicity of voices to consider, as well as the groundedness and continuity in the research process that ethnography proposes are particularly well-suited practices for developing complex understandings of school convivencia.

\section{Ethnography as a Research Method to Analyse School Convivencia}

Ethnography is a long standing qualitative approach that involves the construction of knowledge by accessing and remaining in a setting long enough to gain a deep understanding of the actions and their meanings for the people that constitute it. It is "[...] grounded in commitment to the first-hand experience and exploration of a particular social or cultural setting on the basis of (though not exclusively by) participant observation" (Atkinson et al., 2007, p. 4). Ethnography here is understood as:

[...] the study of people in naturally occurring settings or 'fields' by means of methods which capture their social meanings and ordinary activities, involving the researcher participating directly in the setting, if not also the activities, in order to collect data in a systematic manner but without meaning being imposed on them externally (Brewer, 2000, p. 10).

Ethnography is particularly relevant for the study of school convivencia for several reasons. Firstly, it involves a predominant close contact with the setting, a groundedness that is necessary in order to observe, experience, explore and analyse the tapestry of relationships 
that shape convivencia. According to Hammersley and Atkinson et al. (2007, p. 3) ethnographic research has most of the following features:

1. People's actions and accounts are studied in everyday contexts, rather than under conditions created by the researcher [...], research takes place 'in the field'.

2. Data are gathered from a range of sources, including documentary evidence of various kinds, but participant observation and/or relatively informal conversations are usually the main ones.

3. Data collection is, for the most part, relatively 'unstructured', in two senses. First, it does not involve following through a fixed and detailed research design specified at the start. Second, the categories that are used for interpreting what people say or do are not built into the data collection process [...] Instead, they are generated out of the process of data analysis.

4. The focus is usually on a few cases, generally fairly small-scale, perhaps a single setting or group of people. This is to facilitate in-depth study.

5. The analysis of data involves the interpretation of the meanings, functions, and consequences of human actions and institutional practices, and how these are implicated in local, and perhaps also wider, contexts. What are produced, for the most part, are verbal descriptions, explanations and theories [...].

The unstructured data collection of ethnography that Hammersley and Atkinson mention in the third point is linked to the way that the research aims are structured in this approach. Ethnography usually opts for having general issues as starting points of research, and then, through constant observation, participation and reflection these problems are refined or even transformed: "Eventually [...] the inquiry will become progressively more clearly focused on a specific set of research questions, and this will then allow the strategic collection of data to pursue answers to those questions more effectively, and to test these against evidence" (Hammersley; Atkinson, 2007, p. 3-4). This is a second reason for the relevance in the study of school convivencia because, as I discussed earlier, there are multiple and interrelated relationships among the actors and complex connections with wider social processes and contexts. It can be therefore difficult to develop a set of research aims that are capable of addressing such complexities before accessing the field, and before a detailed knowledge of how that setting works has been gained. In that sense, the openness that ethnography presents allows the researcher to enter the field without rigid views on what to expect and through systematic inquiry develop concrete aims based on the analysis of the elements and relationships of the setting.

The same unstructured position is taken in respect of analysis. Analysis in ethnography is a continuous process that starts from the 
beginning of the research and carries on until the final writing (Brewer, 2000; Coffey; Atkinson, 1996; Hammersley; Atkinson, 2007; Rockwell, 2009). This means that analytic questions are presented, temporarily answered and reshaped from the strategic decisions at the beginning of the research to the final writing process. The movement between empirical data collection and analysis is an important trait of ethnography, and marks the necessity for a continuous reflective stance. Along with ethnographies aims, these characteristic are important for the study of school convivencia, since as an emergent field of study, it needs to be consolidated through the shaping of specific research projects that can shed light on distinctive elements of this concept.

A third reason is that ethnography allows for a deep and complex understanding by taking into consideration different voices and social positions. While studying convivencia, especially from a comprehensive approach, it is necessary to give enough space for a construction of diverse narratives that will allow for a better understanding of the phenomenon. This is done, for example, by using a range of techniques and sources during data collection, observation and participation being the two constitutive features of the ethnographic work (Atkinson et al., 2007; Gobo, 2008). The multiplicity of techniques and the systematic presence of the researcher facilitate the reflection on what works best in different settings in the data collection process and what design or analysis strategies can be most appropriate to the study of social groups.

Linked to these ideas, a fourth reason is that the relationships that the ethnographic approach proposes might enable the researcher to better understand the convivencia in the specific settings, since it requires a close relationship between the researcher and the informants that can promote a more horizontal relationship where actors are able to participate and explain their points of view in their own contexts and by their own decision. This is especially important for studying convivencia in the case of vulnerable groups such as adults or children ${ }^{4}$ in marginalized contexts, like the ones that will be presented in the next section.

Since undertaking an ethnography requires a direct involvement of the researcher, $\mathrm{s} / \mathrm{he}$ is considered to be the main instrument to generate data for the study, s/he must then constantly observe and participate in the social situation. Although a researcher may use everyday practices of social engagement as basis for such participation, what is distinctive here is that:

\begin{abstract}
[...] it involves a more deliberate and systematic approach than is common [...], one in which data are specifically sought to illuminate research questions, and are carefully recorded; and where the process of analysis draws on previous studies and involves intense reflection, including the critical assessment of competing interpretations (Hammersley; Atkinson, 2007, p. 4).
\end{abstract}

It is important to acknowledge as well that the researcher does not neutrally interact and record, s/he is an active social participant who 
must be aware of her/his own position, influence, possibilities and limitations. Different debates around the representation and legitimation of the knowledge constructed by social sciences in general and ethnography in particular (Brewer, 2000; Denzin; Lincoln, 2005; Hammersley, 1998; Hammersley; Atkinson, 2007) have emphasised the importance of addressing processes of reflexivity in research. Self-reflection requires that the researcher acknowledges the implications in the particular context and topic chosen, the role and personal characteristic of the actors and the researcher and how the relationship between them not just influences, but constructs the data. It implies, as Brewer (2000, p. 43) points out that "[...] the ethnographers be explicit and open about the circumstances which produced the extant data, recognizing that ethnographers (like all researchers) are within the social world they seek to analyse".

A reflexive approach also entails the need for the researcher to consider the way the data is being analysed and how this produces a particular account of the social reality: an account that is not neutral and unproblematic, but partial, selective and personal, but that can nevertheless present a view of a problem in society and a possible explanation and perhaps some alternatives for it. In the next part of the article I will explore more the importance of reflecting on the researcher's position in the multiplicity of voices during the study of convivencia in the field. Before this, it is necessary to explore as well the role of theory in ethnography.

Ethnography had traditionally been conceived as being free from theory (at least as a starting point), and as involving an attempt to access the settings as neutrally as possible, proposing to build up theories from the data themselves. This has been called the "[...] theoretical bias" (Hammersley, 1990 apud Brewer, 2000, p. 42). More recent developments, however, have recognized the need to address the role of theory in the research since, as Rockwell (2009, p. 92) states:

[...] each description carries within implicit notions, since there cannot be a 'direct' description of the facts that is not mediated by some mental scheme. A more coherent and intelligible description of a particular situation can be achieved in so far as these notions are made explicit and some relations that articulate the description are formulated in general terms.

Theoretical positioning must be recognized, because it shapes not only the intellectual interests of the researchers, but also the values and expectations one has for the setting and the relationships with the actors.

Finally, it is important to state that ethnography as a method of scientific enquiry produces social knowledge by producing a thick description, in Geertz (1973) terms, which involves not only identifying cultural and social events and patterns, but interpreting their meaning in the context where they are being produced. Originally the approach 
aimed for the possibility of constructing valid universal knowledge, but this claim has been problematized by perspectives such as critical theory, feminism, post-structuralism and postmodernism, that have point out of the challenges related to the failure to recognize issues of power, values, gender, class and race, as well as the points derived from the understanding of science as a social construction and the critiques to the traditional ideas of validity, reliability and generalizability (Brewer, 2000; Denzin; Lincoln, 2005; Hammersley, 1998).

I argue that ethnographic accounts are valid, but not because they can reach a universal objective truth, but because they have a distinctive purpose in studying the everyday life through a systematic perspective. Ethnographic accounts present the possibility of the coconstruction of knowledge by the different actors, although this is only achievable if the researcher is able to open opportunities for exploring diverse accounts of reality. Ethnographic accounts can also help to develop grounded theoretical understandings that can be put into dialogue in different settings. In the case of school convivencia a thick, rich and multiple understanding is needed, because the concept itself demands a complex understanding; an understanding that recognizes not the neutral and objective nature of the explanations constructed, but, rather, acknowledges and analytically explores its groundedness and its social construction. In the next and final section of this paper, I will reflect on how the ideas presented both in the notion of convivencia and in the description of the ethnographic method relate to an ongoing research project. I will describe some of the decisions the researcher must make while linking theory and methodology in the study of school convivencia.

\section{Two Theoretical and Methodological Tensions in the Study of School Convivencia}

The following section presents two tensions that occurred during the fieldwork process in a specific research project that explored school convivencia. Through these challenges I will show that the links between theory, methodology and the researcher position should be considered and problematized, and I will illustrate the ways in which they are embedded in the decisions ethnographic researchers make in the everyday practices of research. These decisions actively shape the research and the possible analytic final constructions and must be explicitly recognized by the researcher immersed in ethnographic processes.

The research to be discussed here comes from a $\mathrm{PhD}$ project studying the relationships between Mexican public primary schools and their local communities, and to analyse the implications of such relationships for school convivencia. The study focused on two public primary schools and their local communities in two Mexican cities, Guadalajara and Ciudad Obregón. These schools were chosen because they are located in vulnerable areas of these cities which present problems related to poverty and social exclusion, as well as their associated issues 
of malnourishment and social violence (especially small-scale drug dealing and gang related activities). Both cities also have presented an increase in armed and drug related violence. One of the key selection criteria was that in these schools the principal and teachers explicitly characterize their own school context and community as violent and/or problematic for the schooling experience. Other criteria were the school size, around 250 students with two groups per grade $\left(1^{\text {st }}-6^{\text {th }}\right)$, and the type and shift of the school: they both were general primaries, one had a morning shift, and one an afternoon one ${ }^{5}$.

The fieldwork was carried out in two stages, the first of which took place from January to April 2015, during which time I carried out participant observation of varied school activities, particularly classes, meetings, recess, and arrival and departure from the school. I also undertook four semi-structured interviews. The second stage of research ran from September 2015 to January 2016 during which time I continued with the participant observation and undertook thirty eight semi-structured interviews across the two schools. The actors involved were mainly students, principals, teachers, parents and grandparents, although other actors related to the school were sometimes talked to as well, such as the women that sold food in the school, substitute teachers and people working in the shops around the schools. In the following sections I will turn to discuss two of the tensions that had to be dealt with during both stages of fieldwork.

\section{Tension Between the Actors and the Researcher's Views on Convivencia}

During fieldwork a first tension gradually emerged between the participants' orientations towards school convivencia and my own as a researcher, a tension that had to be reflected and dealt with by integrating methodological and theoretical aspects. By the constant interaction in the setting and analysis of the day to day data it became clear that the actors' views on what school convivencia was and the perceptions on how to deal with some of the problems of the living together were mainly associated with the students' behaviours. When referring to convivencia the participants mainly described and discussed aggressive behaviour, such as fights, insults and bullying, and lack of compliance with the school's rules. Convivencia in the two schools was 'practiced and dealt-out' by the teachers focusing only on getting evidence and managing of that behaviour. This was made particularly explicit at teachers' meetings, where the number of aggressive individual incidents were counted and represented in graphs so that they could be presented as evidence to the educational system of the school work on convivencia. Such incidents were registered during recess by the teachers in one of the schools, and by the students themselves in the other school. In this second school, a weekly rotating group of students in the role of antibullying guardians wrote the name of the classmates they perceived to be misbehaving or harassing other students. The school's general view on convivencia was therefore situated in a restricted approach (Padilla, 
2013): in the narratives of teachers, principals and even some students, convivencia was presented as a synonym of students' discipline. The notion of convivencia had an instrumental function to aid the improvement and preservation of the school order and was considered important because if convivencia is improved, the undisciplined behaviour will be less (Teacher 2, school 1, 30 January 2016).

Convivencia was also considered important to the schools to comply with the educational policy. As I have mentioned, school convivencia is a national priority in the Mexican Educational System (México, 2014), partly in response to the school and social violence the country has experienced. Since school violence is seen in the policy mainly as a behavioral problem of the students that should be addressed, the educational policy in many of the Mexican states has generally taken a restrictive, punitive approach to address the issue (Rivera, 2012), by focusing on the development of procedures and guidelines to impose sanctions to the students individual behavior. In that sense, schools and policy views are aligned and both set in a restrictive approach to convivencia. Taking a different stance, my own position understands and problematizes the school, and hence the violence within it, as situated or nested in a specific community. I argued that analysing the relationship between the communities and the school is key to understand how the educational institutions deal and interact with the contextual characteristics. This helps to see in detail the real possibilities schools have or do not have for promoting inclusive, democratic and pacific convivencia.

The research was oriented towards the comprehensive perspective (Padilla, 2013). Although since the beginning of the research I explicitly recognized my own position as one aiming for the development of pacific, inclusive and democratic approaches to convivencia, the project did not set as a starting point an ideal of how school convivencia should be, but I intended to adopt an analytical perspective (Evans et al., 2013b) that tries to explain how a particular type of convivencia is constructed and performed in the interactions of a specific context and the implications of such model for the school's everyday life. The challenge was, then, on how to maintain an analytical perspective that faced the different orientations and understanding of school convivencia.

Ethnography has historically opted for giving prevalence to the participant's accounts and their own meanings; in this method it is crucial to attempt to understand the actor's social world from their own perspective. In the case of this research I had to consider, on the one hand, not if the accounts the participants were sharing were valid - they certainly were - but if it was enough to explain the positions of teachers, principals, students and parents in their understanding of school convivencia and point out why these views do not constitute a democratic, inclusive and pacific perspective on convivencia. On the other hand, I had to recognize that my perspective as a researcher expressed in fieldnotes, interview questions, and dialogues carried out in the field, among other things, was in fact another voice present in the setting: a voice that was responsible for building a narrative to explain how a

900 Educação \& Realidade, Porto Alegre, v. 43, n. 3, p. 887-907, July/Sept. 2018. 
fabric of convivencia was constructed in schools, and therefore, it was impossible and unethical to ignore.

I chose, then, to make the dialogue between the two perspectives explicit. I deepened my understanding of what the actors associated as school convivencia, but at the same time, I integrated data on other areas that the participants did not explicitly relate to the management of convivencia, but were pointed out from my theoretical analysis and personal perspective. I hence included elements such as peer collaboration among the students, formative ways of dealing with conflicts, the construction of trust or mistrust among actors, the role of responsibility or blame in school conflicts, as well as negotiations of the meanings of appropriate relationships in the school and with the families. These elements provided a more situated understanding on the type of relationships among the actors and their implications for school convivencia, and they also allowed me to integrate the socio-communitarian level that was absent when looking at convivencia only from the student's behaviour perspective.

\section{Tension Between the 'Fragmentation Risk' and the Complex in Studying Convivencia}

The second tension found during fieldwork relates to delineating what school convivencia is for analytical purposes and how can it be seen in the field, without losing the complexity that the concept from a comprehensive perspective, as proposed by Padilla (2013), demands. For several reasons, school convivencia is a tricky concept to work with during qualitative research. I will point to two aspects that presented challenges during the research on school and community relationships and their implications for school convivencia. The first one is that the comprehensive approach situates the notion of convivencia as interrelated with other academic fields like democratic and citizenship education, moral education and peace education. The notion of school convivencia is nurtured by those fields and it gives back a concrete setting where ideas such as inclusion, participation, conflict resolution, socio-emotional development, etc., take place. The link between convivencia and the above mentioned fields make convivencia a dynamic concept that can connect with different ideas and interventions that emerge from such areas, but at the same time the limits between perspectives are blurred, making it hard to point out where the boundaries of the concept are.

The second aspect is that convivencia emerges from and happens in the everyday life of schools. The notion focuses on the little things that comprise the relationships in the school and that are lived every day by the school actors. Greetings, rules, fights, agreements, tone of voice, management decisions, physical spaces, modes of participations, etc. are all shaped by and shape the fabric of school convivencia. By being aware of this complexity in the field, the question of what is or what is not school convivencia becomes harder to answer, and so does creat- 
ing boundaries during the analysis. As a researcher, it can feel as if every interaction is relevant to understand convivencia, because one is aware of the intricacy of the relationships and the fluidity of social negotiations.

The interrelation to other fields and the focus on relationships on the everyday life makes convivencia a multifaceted concept. The question I constantly faced was how to deal with a complex understanding of convivencia while constructing and analysis data. Previous work have attempted to maintain a wide understanding of convivencia, but focus on specific elements to explore it an analyse it; in such works, levels of convivencia are set up, specific practices that improve convivencia are chosen or indicators to measure convivencia developed (i.e. CasoLópez et al., 2015; Evans; Ollivier, 2012; Hirmas; Carranza, 2009). This seems to be a valid way of approaching convivencia, because it takes a comprehensive perspective that recognize the multiplicity of interrelationships that shape it, developing from this understanding focus of research, dimensions or indicators. However there is also the risk of braking the concept down to a list of actions or opinions on the quality of convivencia, without linking the findings back to the notion of the multiplicity of interrelationships, and in turn escaping the complexity that the concept demands from the beginning (see the analysis on measures of convivencia in Franco; Castañeda; Parada, 2014).

I call this possibility of oversimplifying the reality a fragmentation risk, and it became a continuous concern while choosing foci of observation and analysis. The challenge was how to explore specific practices without deterring the engagement with the notion of the tapestry of social relations that form school convivencia. In other words, I was faced with the question of how to analyse everyday actions without separating them from their context, without somehow positioning them as variables to be dealt with. Ethnography as a method proved to be a way of dealing with this complexity. The continuous presence in the field allowed me to follow sets of interactions for several days in context, to ask the actors about their different views while things were happening and after they had happened, and observe some of the implications of these sets of interactions for the rest of the school. For example, in the antibullying guardians programme referred above I could have only analysed what the aims of the programme were, how it was implemented, the people involved, and their views on its relevance and implications for the aggressive behaviour they were reporting. However, by remaining in the setting for several months I was able to experience how teachers referred to the programme and how actually expected the students to carry out the reports, the importance (or otherwise) that the students were giving to being written up for aggressive behaviour, or to having the responsibility of monitoring and policing their classmates, the parent's perspective on the programme, and even what happened during the weeks that the programme did not run.

I found out, for example, that there was a common practice of the older male students from $6^{\text {th }}$ and $5^{\text {th }}$ grade of harassing the younger stu- 
dents. The programme did not change the practices, and the students did not feel the aggression was less frequent, but when the harassed students were guardians they felt protected by their role, not only because they could accuse the older students, but because the written report was a way of having the attention of the teacher, if the student wanted it, and therefore, of having power over the older students. What matter most for students, and their parents as well, was the possibility of reporting the aggression, more than the expectation of solving the problem, teachers dealing with the issue, or of consequences for the aggressive students. Continuously reflecting about the relationships and its implications also allowed me to ask what represented a programme like this in this particular school, in this particular context, were, for example, aggressive physical behaviour is common in the life of many of the students and their families. I could also explore what it meant for those teachers to deal with perceived aggressive behaviour in such way, and how it connects to a general construction of the convivencia in school.

The ongoing analysis process that ethnography entails allowed me therefore to be aware of the fragmentation risk itself and actively reflect on the type of data I was constructing, the type of voices I was hearing and how these shaped the convivencia in the everyday praxis. I must acknowledge that the data collection-analysis duo occurred during fieldwork was not an easy process and I had to make decisions that reduced the multiplicity in order to grasp and construct explanations, defining, for example, specific areas of convivencia to analyse, but the process ethnography proposes while the researcher is in the field allowed me to gain insights into the complexity of the relations that happened in the fluid everyday life.

\section{Conclusion}

This article has aimed to show why ethnography is a relevant approach in the study of school convivencia by first discussing the concept of and how it has been used in in a restricted and comprehensive way, following Padilla's (2013) understanding, then presenting the reasons for taking an ethnographic approach for analysing school convivencia, and finally describing two tensions found during fieldwork in a particular research of school convivencia in two Mexican primary schools: the tension in dealing with the differences between the actors and the researcher's views on convivencia, and the tension to avoid the fragmentation risk, trying to study specific practices of convivencia without separating them from their contexts. These tensions served to illustrate the link between theoretical and methodological components, and the need to address the complexity of such ties during fieldwork. They also show how an in-depth, continuous, systematic and analytic presence in the field, such as the one proposed by ethnography might be a way of dealing with this tensions.

The challenge of understanding and working with convivencia in school is to not lose sight of its complexity to really stand from com- 
prehensive perspectives that can allow for the re-shaping of meaningful relationships that can construct models of pacific, inclusive and democratic convivencia. It is analysing how multi-layered actions in context shape convivencia and how understanding and intervening in school convivencia should be approached in such complexity, rejecting instrumental linear positions based on managing school violence. For example in the illustration given of the anti-bullying programme, an ethnographic approach allowed me to question not just the actions of carrying out the programme itself, but what the programme meant for those particular actors and the implications for school convivencia.

The academic field of school convivencia needs a more grounded and analytic research to develop a better understanding of how convivencia is experienced in the everyday of schools, looking and how the actors understand it, what makes it problematic and what social and cultural resources come into play in the different relationships that form it. Ethnography, as I have argued, can provide an important and productive approach to its study. More systematic grounded studies can help us see how school convivencia is actually shaped by the actors and with such understanding develop more comprehensive educational policies that go beyond the controlling of the behaviour of the students to ensure the fulfilment of the right to education in the everyday of the teachers, parents and students ${ }^{6}$.

Received on July 06, 2017

Approved on November 20, 2017

\section{Notes}

1 Jares continues this idea expressing the need that an education for convivencia and for democratic citizenship should be considered a matter of State, along with the rest of education.

2 Parallel links can be drawn to the discussion of status-based and instrumental approaches in the human rights within education analysis that McCowan (2012; 2013) presents.

3 Most of the literature on school convivencia relates to the field of school leadership in one way or another, because it takes into consideration how relationships are shaped by pedagogical and administrative practices, as well as by educational policy (Evans, 2013; Onetto, 2004), in an effort to promote better types of convivencia in schools.

4 Since 1997 James and Prout (2015, p. 10) in exploring the New Sociology of Childhood key features, establish that "[...] ethnography is a particular useful methodology for the study of childhood. It allows children a more direct voice and participation in the production of sociological data than is usually possible through experimental or survey styles of research".

5 Primary schooling system is organized in two shifts: morning ( $7: 30 \mathrm{am}-12: 00$ $\mathrm{pm})$, and evening (2:00 - 6:30 pm); and there are different types of primary schools: general, indigenous, bilingual, etc.

6 The author is thankful for the careful reading and useful comments provided by Dr. Will Gibson and Dr. Tristan McCowan.

904 Educação \& Realidade, Porto Alegre, v. 43, n. 3, p. 887-907, July/Sept. 2018 


\section{References}

ARARTEKO. Convivencia y Conflictos en los Centros Educativos. Madrid: Gráficas Santamaría, 2006.

ARGENTINA. Ministerio de Educación y Deportes. Programa Nacional de Convivencia Escolar. Buenos Aires: Ministerio de Educación de la Nación, 2010. Available on: <http://portal.educacion.gov.ar/?page_id=347>. Access in: 8 Apr. 2016.

ATKINSON, Paul et al. Handbook of Ethnography. London: SAGE, 2007.

BREWER, John. Ethnography. Buckingham: Open University Press, 2000.

CABALLERO GRANDE, María José. Convivencia Escolar: un estudio sobre buenas prácticas. Revista de Paz y Conflictos, Granada, v. 3, p. 154-169, jun. 2010.

CASASSUS, Juan. La Escuela y la (Des)Igualdad. México: Castillo, 2005.

CASO-LÓPEZ, Alicia Chaparro et al. Desarrollo de un Instrumento de Evaluación Basado en Indicadores de Convivencia Escolar Democrática, Inclusiva y Pacífica. Perfiles Educativos, Ciudad de México, v. 37, n. 149, p. 20-41, 2015.

CHILE. Política de Convivencia Escolar. Santiago de Chile: MINEDUC, 2002

COFFEY, Amanda; ATKINSON, Paul. Making Sense of Qualitative Data. Thousand Oaks: SAGE, 1996

DENZIN, Norman; LINCOLN, Yvonna. The SAGE Handbook of Qualitative Research. Thousand Oaks: Sage Publications, 2005.

DONOSO, María Aird. Gestión de la Convivencia y Solución de Conflictos en Centros Educativos. Revista Iberoamericana de Educación, Madrid, v. 59, n. 2, p. 1-14, 2012.

EVANS, María Cecilia Fierro et al. Conversando sobre la Convivencia en la Escuela: una guía para el auto-diagnóstico de la convivencia escolar desde las perspectivas docentes. Revista Iberoamericana de Evaluación Educativa, Madrid, v. 6, n. 2, p. 103-124, 2013a.

EVANS, María Cecilia Fierro et al. Convivencia Escolar: un tema emergente de investigación educativa en México. In: MALAMUD, Alfredo Furlán; SCWARTZ, Terry Carol Spitzer (Ed.). Convivencia, Disciplina y Violencia en las Escuelas: 2002-2011. México D.F.: ANUIES-COMIE, 2013b.

EVANS, María Cecilia Fierro. Convivencia Inclusiva y Democrática: una perspectiva para gestionar la seguridad escolar. Sinéctica, Guadalajara, n. 40, p. 1-18, 2013.

EVANS, María Cecilia Fierro; OLLIVIER, María Bertha Fortoul. Presentación: convivencia y aprendizaje. Revista Latinoamericana de Educación Inclusiva, Santiago de Chile, v. 6, n. 2, p. 17-22, 2012.

FRANCO, Cristina Perales; CASTAÑEDA, Eduardo Arias; PARADA, Miguel Bazdresch. Desarrollo Socioafectivo y Convivencia Escolar. Guadalajara: ITESO, 2014.

FRANCO, Cristina Perales; CASTAÑEDA, Eduardo Arias; PARADA, Miguel Bazdresch. La Convivencia Escolar desde la Voz de los Alumnos. Revista Iberoamericana de Evaluación Educativa, Madrid, v. 6, n. 2, p. 147-165, 2013.

GALTUNG, Johan. Violence, Peace and Peace Research. Journal of Peace Research, London, v. 6, n. 3, p. 167-191, 1969.

Educação \& Realidade, Porto Alegre, v. 43, n. 3, p. 887-907, July/Sept. 2018. 
GALTUNG, Johan. Three Approaches to Peace: peacekeeping, peacemaking, and peacebuidling. In: GALTUNG, Johan (Ed.). Peace, War, and Defence: essays in peace research: volume II. Copenhagen: Christian Ejlers, 1976. P. 282-304.

GALTUNG, Johan. Peace by Peaceful Means: peace and conflict, development and civilization. London: SAGE, 1996.

GEERTZ, Clifford. The Interpretation of Cultures: selected essays. New York: Basic Books, 1973.

GOBO, Giampietro. Doing Ethnography. London: SAGE, 2008.

HAMMERSLEY, Martyn. Reading Ethnographic Research: a critical guide. Essex: Longman, 1998.

HAMMERSLEY, Martyn; ATKINSON, Paul. Ethnography: principles in practice. London: Routledge, 2007.

HIRMAS, Carolina; CARRANZA, Gloria. Matriz de Indicadores sobre Convivencia Democrática y Cultura de Paz en las Escuelas. In: JORNADAS DE COOPERACIÓN IBEROAMERICANA SOBRE EDUCACIÓN PARA LA PAZ, LA CONVIVENCIA DEMOCRÁTICA Y LOS DERECHOS HUMANOS, 3., 2009, Santiago de Chile. Anais... Santiago de Chile: UNESCO, 2009. P. 56-136.

HIRMAS, Carolina; EROLES, Daniela. Convivencia Democrática, Inclusión y Cultura de Paz: lecciones aprendidas desde la práctica innovadora en América Latina. Santiago de Chile: OREALC/UNESCO Santiago, 2008.

IANNI, Norberto Daniel. La Convivencia Escolar: una tarea necesaria, posible y compleja: monografías virtuales. Ciudadanía, Democracia y Valores en Sociedades Plurales, Madrid, v. 2, n. Ago./Sept. 2003.

JAMES, Allison; PROUT, Alan. Constructing and Reconstructing Childhood: contemporary issues in the sociological study of childhood. London: Taylor \& Francis, 2015.

JARES, Xesus. Pedagogía de la Convivencia. Barcelona: Grao, 2006.

MCCOWAN, Tristan. Human Rights within Education: assessing the justifications. Cambridge Journal of Education, Cambridge, v. 42, n. 1, p. 67-81, mar. 2012.

MCCOWAN, Tristan. Education as a Human Right. London: Bloomsbury Publishing, 2013.

MÉXICO. Acuerdo número 717 por el que se emiten los lineamientos para formular los Programas de Gestión Escolar, Diário Oficial de la Federación, Ciudad de México, 7 mar. 2014. Available on: <http://dof.gob.mx/nota_detalle.php? codigo $=5335233 \&$ fecha $=07 / 03 / 2014>$. Access in: 11 May 2015

OECD. PISA 2012 Results: what makes schools successful (volume IV). Paris: OECD Publishing, 2013.

ONETTO, Fernando. Climas Educativos y Pronósticos de Violencia: condiciones institucionales de la convivencia escolar. Madrid: Noveduc Libros, 2004.

ORTEGA-RUIZ, Rosario; DEL REY, Rosario; CASAS, José. La Convivencia Escolar: clave en la predicción del bullying. Revista Iberoamericana de Evaluación Educativa, Madrid, v. 6, n. 2, p. 91-102, 2013.

PADILLA, Patricia Padilla. Convivencia Democrática en las Escuelas: apuntes para una reconceptualización. Revista Iberoamericana de Evaluación Educativa, Madrid, v. 6, n. 2, p. 13-35, 2013.

PARADA, Miguel Bazdresch. La Vida Cotidiana Escolar en la Formación Valo-

906 Educação \& Realidade, Porto Alegre, v. 43, n. 3, p. 887-907, July/Sept. 2018. 
ral: un caso. Revista Iberoamericana sobre Calidad, Eficacia y Cambio en Educación, Madrid, v. 7, n. 2, p. 50-71, 2009.

PERU. Normas y Orientaciones para el Desarroll del Año Escolar 2015 en la Educación Básica. Lima: MINEDU, 2015. Available on: <http://www.minedu. gob.pe/campanias/pdf/norma_tecnica_eb2015.pdf>. Access in: 8 Apr. 2016

RIVERA, Úrsula Zurita. Las Escuelas Mexicanas y la Legislación sobre la Convivencia, la Seguridad y la Violencia Escolar. Educación y Territorio, Tunja, v. 2, n. 1, p. 19-36, 2012.

ROCKWELL, Elsie. La Experiencia Etnográfica. Buenos Aires: Paidós, 2009.

UNESCO. Los Aprendizajes de los Estudiantes de América Latina y el Caribe: primer reporte de los resultados del segundo estudio regional comparativo y explicativo. Santiago, Chile: OREALC/UNESCO, 2008.

UNESCO. III Jornadas de Cooperación Iberoamericana sobre Educación para la Paz, la Convivencia Democrática y los Derechos Humanos. San José de Costa Rica: UNESCO - IIDH, 2009.

VÁZQUEZ, Pedro Gallardo. Educación Ciudadana y Convivencia Democrática. Pedagogía Social - Revista Interuniversitaria, Murcia, n. 16, p. 119-133, 2009.

Cristina Perales Franco is a PhD Student in Education at the University College London (UCL) Institute of Education. Her main research explores the relationships between Mexican schools situated in vulnerable areas and their local communities, focusing on the implications for school convivencia. She has published in Mexico and internationally in the areas of education and social relationships, inclusion and exclusion processes, and convivencia.

E-mail: cristinaperalesf@gmail.com

This is an open-access article distributed under the terms of the Creative Commons Attribution License 4.0 International. Available at: <http://creativecommons.org/licenses/by/4.0>. 